\title{
Psikodrama untuk Self-Esteem Anak dengan Specific Learning Disorder Usia 9-12 Tahun
}

\author{
Nyi Mas Ratu Rema ${ }^{1}$ \\ Fakultas Psikologi, Program Studi Psikologi Profesi (S2), Universitas Padjadjaran \\ nyi17001@mail.unpad.ac.id \\ Afra Hafny Noer ${ }^{2}$ \\ Fakultas Psikologi, Program Studi Psikologi Profesi (S2), Universitas Padjadjaran \\ afra@unpad.ac.id

\section{Esti Wungu $^{3}$} \\ Fakultas Psikologi, Program Studi Psikologi Profesi (S2), Universitas Padjadjaran \\ esti.wungu@unpad.ac.id
}

\begin{abstract}
Out of 50 million Indonesian children, 5 million children have experience learning difficulties. Exams, achievement, and literacy are a big challenge for children with specific learning disorder (SLD). Children with SLD are often stigmatized and associated with failures that lower their self-esteem. Children's low self-esteem is the result of negative self-assessment and self-quality. This psychodrama module aims to increase low self-esteem in children with specific learning disorders aged 9-12 years. The design of the module is made using an instructional system design approach and the research method in the trial phase uses a quasi-experimental method with a small design research design one group pre-test-post test. Data were collected using interviews, observation, and self-esteem questionnaires. The design of this module goes through a due diligence process carried out by 3 expert judgments and trials on 9 children aged 9-12 years who have low self-esteem. Based on the results obtained to increase low self-esteem in children aged 9-12 years, the psychodrama module emphasizes the material areas of friends and school, sculpture techniques, and repetitive processes
\end{abstract}

Keywords: intervention, psychodrama, self-esteem, specific learning disorder

\begin{abstract}
Abstrak
Di Indonesia sebanyak 5 juta dari 50 juta anak-anak mengalami kesulitan belajar. Ujian, prestasi dan literacy, merupakan tantangan yang besar untuk anak specific learning disorder (SLD). Anak dengan SLD sering distigmatisasi dan dikaitkan dengan kegagalan yang menurunkan self-esteem. Self-esteem rendah adalah hasil penilaian negatif terhadap diri dan kualitas diri yang memberikan dampak buruk bagi anak. Modul psikodrama ini bertujuan untuk meningkatkan self-esteem rendah pada anak dengan specific learning disorder usia 9-12 tahun. Rancangan modul dibuat menggunakan pendekatan instructional system design dan metode penelitian
\end{abstract}


tahap uji coba menggunakan metode quasi eksperimen dengan desain penelitian small design one group pre test-post test. Pengambilan data menggunakan interview, observasi dan pengisian kuesioner self-esteem. Rancangan modul ini melewati proses uji kelayakan yang dilakukan oleh 3 orang expert judgement dan uji coba pada 9 orang anak usia 9-12 tahun yang memiliki self-esteem rendah. Berdasarkan hasil yang diperoleh untuk meningkatkan self-esteem rendah pada anak usia 9-12 tahun, maka dalam modul psikodrama menekankan pada materi area teman dan sekolah, teknik sculpture, dan proses berulang

Kata kunci: intervensi, psikodrama, self-esteem, specific learning disorder

\section{PENDAHULUAN}

Data mengenai anak dengan SLD khususnya disleksia di Indonesia, menurut ketua asosiasi disleksia Indonesia terdapat 10\% - 15\% anak sekolah menyandang disleksia (Riyani T. Bondan, 2019). Dengan jumlah anak sekolah di Indonesia sekitar 50 juta, diperkirakan 5 juta diantaranya mengalami disleksia.

Specific Learning Disorder (SLD) adalah kesulitan belajar dan adanya kesulitan menggunakan kemampuan-kemampuan akademis, diindikasikan dengan kehadiran paling tidak satu dari simptom-simptom yang telah bertahan paling sedikit 6 bulan. Kesulitan tersebut mencakup kesulitan membaca, kesulitan memahami bacaan, kesulitan dalam ejaan, kesulitan dengan ekspresi tertulis, kesulitan menguasai jumlah angka, jumlah fakta atau penjumlahan, kesulitan dengan penalaran matematika. Hal ini merupakan gangguan neurologis yang mempengaruhi kemampuan otak untuk menerima, memproses, menyimpan, dan merespons informasi (Clauss-Ehlers, 2010).

Seorang anak dengan Specific Learning Disorder (SLD) memiliki tantangan belajar yang ekstrim, kesulitan akademis dan perlu diberikan dukungan pendidikan khusus. Sekolah pada umumnya sangat memperhatikan hal-hal yang berkaitan dengan ujian, prestasi dan literacy. Hal ini bisa menjadi tantangan untuk anak dengan SLD terutama untuk anak usia 912 tahun yang bersekolah di sekolah umum. Karena, dalam rentang usia ini, kebanyakan sekolah umum akan menganggap bahwa anak seharusnya telah menguasai kemampuan membaca (Foss, 2013). Sekolah merupakan institusi sosial, di mana terdapat aturan umum yang berlaku di sekolah dan membuat anak dengan disleksia kesulitan untuk mengikuti aturan dan kesulitan untuk menyesuaikan diri dengan sekolah.

Anak dengan SLD sering distigmatisasi dan dikaitkan dengan kegagalan, yang menurunkan harga diri. Kegagalan yang sering dirasakan menumbuhkan kesadaran bahwa 
anak tidak sama dengan lingkungan, sehingga dapat membuat terisolasi secara sosial dan bisa menjadi sumber ketidakbahagiaan yang kronis (Reid, 2011). Lebih lanjut disebutkan pula bahwa situasi tidak menyenangkan yang dialami oleh anak dengan SLD di sekolah ini membuat anak membentuk konsep diri yang negatif. LaBarbera (2008) menemukan bahwa individu dengan kesulitan belajar mengembangkan self-perception negatif tentang diri mereka sendiri, berbeda dengan individu yang tidak memiliki kesulitan belajar.

Individu dengan pengalaman kesulitan belajar memiliki self-esteem rendah, karena kegagalan yang sering dialami oleh dirinya (Westwood, 2004). Penelitian oleh Riddick (2010) menyebutkan bahwa kondisi anak dengan SLD berdampak pada self-esteem dari anak yaitu mereka dapat mengembangkan masalah sosial dan emosional. Self-esteem adalah hasil evaluasi tentang diri sendiri, artinya individu tidak hanya menilai diri sendiri, tetapi juga menilai kualitas diri. Self-esteem mempengaruhi proses belajar maupun hasil kinerja dan begitu pula sebaliknya (Ruly, 2016). Anak perlu menyadari kekuatan belajar mereka yang unik, sehingga dapat menerapkannya secara efektif untuk memperkuat hal-hal yang tertinggal ketika mereka mengakui dan menerima keadaan diri (Burden, 2008; Falzon \& Camilleri, 2010). Anak yang menerima keadaan diri dapat belajar bagaimana mengatasi dan mengelola kesulitan, melihat hasil positif dan pencapaian yang memadai, sehingga meningkatkan self-esteem (Burden, 2008; Falzon \& Camilleri, 2010).

Pada usia 9-12 tahun dalam aspek sosial, anak menjadi lebih sadar terhadap dirinya sendiri. Kesadaran anak terhadap dirinya sendiri diperkuat melalui impresi yang diserap oleh sang anak terhadap apa yang dilihat, didengar, dibaca, dirasa dan dipikirkannya. Kesadaran ini pada akhirnya turut membantu evaluasi anak terhadap dirinya semakin kompleks sehingga berkaitan dengan self-esteem anak. Anak dengan SLD mengalami banyak kesulitan dan kegagalan, sehingga berpengaruh pada self-esteem berakiatan dengan evaluasi diri dan berfokus pada hal negatif yang ada di dalam diri. Anak pada usia ini, terkait aspek kognitifnya, anak sudah memiliki kemampuan untuk mempertimbangkan banyak sudut pandang, berbagai strategi ingatan mulai meningkat, dan anak sudah mampu menarik kesimpulan-menganalisa (Santrock, 2009).

Aspek emosi anak usia 9-12 tahun mengalami peningkatan kemampuan untuk menahan emosi kompleks, misalnya muncul rasa kebanggan dan rasa malu. Emosi kompleks ini menjadi lebih terinternalisasi dan terintegrasi dengan tanggung jawab personal. Terdapat peningkatan kecenderungan untuk lebih mempertimbangkan kejadian-kejadian yang menyebabkan reaksi 
emosi tertentu untuk menekan atau menutupi reaksi emosional yang negatif (Santrock, 2009). Self-esteem merupakan dasar atau motif seseorang dalam berhubungan dengan orang lain. Anak dengan SLD, pada umumnya cenderung menunjukkan perhatian lebih pada informasi negatif mengenai diri mereka setelah mengalami berbagai macam kegagalan sehingga dapat berpengaruh dalam membangun relasi positif (Swam dan Bosson, 2010)

Humphrey dan Mullins (2002) mencatat bahwa semakin bertambah usia anak dengan disleksia mengalami tantangan dan kesulitan yang signifikan berkaitan dengan self-esteem dan persepsi dirinya. Kesulitan tersebut dapat diatasi dengan kurikulum dan pedagogi inklusif yang baik dan melalui penggunaan drama (Eaden \& BDA, 2005; McNulty, 2003). Pendidikan drama sebagai salah satu metode seni merupakan metode yang efektif untuk memahami, memonitor, dan memelihara atau meningkatkan konsep diri (Roche, 1996). Psikodrama telah dikembangkan sejak tahun 1974, dikenal sebagai salah satu metode psikoterapi kelompok efektif yang digunakan ketika perasaan dan pikiran negatif ini menjadi masalah bagi individu (Holmes; Wilkins,1999). Psikodrama menggunakan permainan peran sebagai media terus berkembang, dapat dilihat dari beberapa penelitian, diantaranya yang dilakukan oleh Narimani, Biabangard \& Rajabi (2006) yang menunjukan bahwa psikodrama memberikan dampak yang signifikan pada kemampuan interpersonal dan self-esteem namun tidak pada ego dan perilaku belajar.

Psikodrama adalah teknik yang memberikan kesempatan individu untuk melihat kehidupan pribadi dengan sudut pandang berbeda, yaitu setelah kehidupan pribadinya didramakan dan dimainkan oleh orang lain yang berada dalam kelompok bersamanya (Moreno; Dzokic, 2009). Corey (2005) menyatakan dengan metode psikodrama, individu dapat mengubah dan memperoleh pengertian lebih baik tentang dirinya, menemukan konsep dirinya, menyatakan kebutuhan, dan reaksi tekanan terhadap dirinya.

Anak dengan disleksia dapat mudah melakukan kegiatan bermain peran karena memiliki keterampilan visual dan kreativitas yang kuat (Davis \& Braun, 2010). Mereka juga cenderung sadar akan lingkungan dan karena itu sangat intuitif dan perseptif, sangat baik dalam menghubungkan gerakan dengan berbicara, dan sangat tertarik dalam keterampilan pengamatan (Dyslexia Scotland, 2007). Eadon (2005) mencatat bahwa anak-anak memandang psikodrama membantu mereka mendapatkan kepercayaan diri, koordinasi, dan keterampilan sosial. 
Pelaksanaan metode psikodrama dapat membuat anak lebih paham mengenai suatu permasalahan terkait dengan dirinya. Hal tersebut dikarenakan pemahaman yang dilakukan berulang kali sebelum diaplikasikan dalam kehidupan sehari-hari. Penerapan metode psikodrama menggambarkan suatu bentuk peristiwa aktif yang dibuat melalui drama menggunakan garis besar cerita sehingga menimbulkan penghayatan dan pemahaman individu tentang peristiwa tersebut. Aspek pemahaman ini terdapat dalam komponen belief system setelah pemahaman dilakukan berulang-ulang maka akan timbul reaksi yang timbul yang merupakan suatu bentuk ungkapan berpikir individu yang merasa telah mendapat kejelasan dari hasil pemahaman tadi sebagai proses belajar (Biggt Morris, 1976).

Psikodrama akan membantu anak untuk mengatasi masalah-masalah pribadi dengan bermain peran dalam sebuah drama. Anak akan dibantu untuk mengungkapkan perasaan yang menimbulkan konflik. Permainan peran dalam psikodrama memiliki tujuan agar individu memperoleh pengertian lebih baik, menemukan konsep diri, menyatakan kebutuhan dan menyatakan reaksi terhadap tekanan dalam diri. Manfaat penting dalam psikodrama, pertama manfaat katarsis atau melepaskan emosi. Manfaat yang kedua adalah melihat sesuatu dari sudut pandang orang lain (Corey, 2005).

Psikodrama memberikan kesempatan perlakukan pada anak dengan SLD yang memiliki self-esteem rendah untuk dapat mengekspresikan emosi yang sebelumnya terpendam dalam bentuk peran tertentu, agar terjadi katarsis emosi sehingga anak menjadi lebih sehat secara mental, sehingga dalam penelitian ini dibuat modul psikodrama untuk meningkatkan self-esteem rendah pada anak dengan specific learning disorder usia 9-12 tahun. Psikodrama sebagai terapi yang menggunakan permainan peran sebagai media terus berkembang, dapat dilihat dari beberapa penelitian yang dilakukan. Penelitian yang berjudul; "The Impact Of Psychodrama On Social Skills And Self Esteem Of Elementary School Students With Dyslexia" (Narimani, Biabangard \& Rajabi, 2006) menunjukan bahwa psikodrama memberikan dampak yang signifikan pada kemampuan interpersonal dan harga diri namun tidak pada ego dan perilaku belajar.

Tujuan penelitian ini adalah memperoleh modul intervensi psikodrama yang telah di uji coba (pilot testing) pada anak dengan self-esteem rendah. Psikodrama digunakan sebagai salah satu metode intervensi psikologis yang nantinya dapat digunakan untuk meningkatkan self-esteem rendah pada anak dengan specific learning disorder pada usia 9-12 tahun. Kegunaan penelitian ini adalah memberikan gambaran dan menambah referensi mengenai 
metoda intervensi untuk anak dengan specific learning disorder yang memiliki self-esteem rendah.

\section{METODE}

Pada penelitian ini dilakukan dalam 2 tahap studi, yaitu : studi I adalah perancangan modul psikodrama dan studi II adalah uji coba modul psikodrama. Penelitian ini mendapatkan persetujuan dari Komisi Etik Universitas Padjadjaran Bandung (No. 1210/UN6.KEP/EC/2019) pada tanggal 25 September 2019.

Gambar 1.

Fase-Fase Penelitian

\begin{tabular}{|c|c|}
\hline $\begin{array}{c}\text { STUDI I } \\
\text { PERSIAPAN }\end{array}$ & $\begin{array}{c}\text { STUDI II } \\
\text { PENGEMBANGAN }\end{array}$ \\
\hline $\begin{array}{l}\text { (1) Instructional Problems } \\
\text { Menggali mengenai self-esteem anak dengan } \\
\text { disleksia mengenai treatment yang sesuai }\end{array}$ & $\begin{array}{l}\text { (5) Uji Coba Modul Psikodrama } \\
\text { Pretest } \\
\text { Pelaksanaan uji coba modul }\end{array}$ \\
\hline$\longleftarrow$ & Posttest \\
\hline $\begin{array}{l}\text { (2) Instructional Objectives } \\
\text { Penetapan Tujuan }\end{array}$ & $\leftarrow$ \\
\hline $\begin{array}{l}\text { (3) Instructional Strategies } \\
\text { - Penetapan Materi } \\
\text { - Penetapan Teknik } \\
\text { - Penetapan alat penunjang } \\
\text { - Penetapan waktu kegiatan } \\
\text { - Penetapan ruangan kegiatan }\end{array}$ & $\begin{array}{l}\text { (6) Evaluasi Hasil Uji Coba } \\
\text { Evaluasi reaksi penangkapan } \\
\text { peserta terhadap materi, teknik, alat } \\
\text { penunjang, alokasi waktu, dan } \\
\text { penataan ruang dan hasil penelitian } \\
\text { berdasarkan hasil uji coba }\end{array}$ \\
\hline$\longleftarrow$ & \\
\hline $\begin{array}{l}\text { (4) Evaluation Instrument } \\
\text { Rancangan evaluasi dan alat ukur }\end{array}$ & $\begin{array}{l}\text { (7) Revisi Modul Psikodrama } \\
\text { Melakukan revisi dan modifikasi } \\
\text { guna memperbaiki kekurangan } \\
\text { pada modul psikodrama } \\
\text { berdasarkan hasil uji coba }\end{array}$ \\
\hline \multirow{2}{*}{$\begin{array}{l}\text { Rancangan Modul Psikodrama } \\
\text { Modul psikodrama untuk meningkatkan self- } \\
\text { esteem rendah pada anak dengan specific learning } \\
\text { disorder berdasarkan hasil review expert } \\
\text { judgement }\end{array}$} & \\
\hline & Modul Psikodrama \\
\hline
\end{tabular}

\section{Tahap Studi I}

Dalam studi I, penyusunan modul dibuat menggunakan pendekatan instructional system design (Morrison, 2012) yang terdiri dari instructional problem, instructional objectives, 
instructional strategies, evaluation instruments serta proses review dari 3 orang expert judgement yang terdiri dari praktisi psikodrama dan psikolog. Pada tahapan instructional problem peneliti melakukan need asesment untuk melakukan analisis terhadap tujuan serta menetapkan prioritas yang akan dimunculkan dalam pembuatan modul. Pengambilan data dilakukan melalui teknik observasi pada 5 orang anak yang dikeluhkan mengalami kesulitan belajar dan memiliki self-esteem rendah, wawancara kepada 4 orang guru dan 2 orang tua yang menangani permasalahan anak dengan specific learning disorder usia 9-12 tahun terkait dengan permasalahan self-esteem rendah serta kajian literatur mengenai anak dengan specific learning disorder dan permasalahan self-esteem. Analisis hasil dilakukan dengan cara kategorisasi hasil interview ataupun observasi dengan menggunakan kajian pustaka literasi. Dalam tahapan ini peneliti menganalisis gambaran yang lebih mendalam mengenai anak dengan SLD yang memiliki self-esteem rendah serta menentukan pengetahuan dan prosedur yang akan digunakan dalam proses pembuatan modul.

Tahap Instructional Objectives dilakukan penetapan tujuan berdasarkan hasil dari need assessment yang sudah dilakukan sebelumnya. Tujuan umum dari rancangan modul psikodrama ini adalah meningkatkan self-esteem rendah bagi anak dengan specific learning disorder usia 9-12 tahun. Diharapkan anak dapat menerima tampilan diri dengan lebih positif dan muncul kesediaan dalam dirinya untuk mengubah ke arah positif. Tujuan ini kemudian diturunkan menjadi tujuan yang lebih spesifik berdasarkan tahapan psikodrama di dalam setiap sesinya. Tujuan dimunculkan berdasarkan hasil analisis capaian yang ingin dimunculkan terkait dengan perilaku self-esteem serta tujuan dasar dari setiap tahapan psikodrama. Tujuan juga dikaitkan dengan teori self-esteem dari Coopersmith yang menyasar 4 aspek self-esteem dalam 4 area kehidupan seorang individu., yaitu power, virtue, significance, dan competence. Penetapan tujuan ini merupakan dasar yang digunakan dalam penyusunan materi dan teknik dalam modul psikodrama.

Pada tahap Instructional Strategies peneliti menentukan strategi penyusunan yang terdiri dari 5 hal, yaitu rincian tahapan kegiatan setiap sesi psikodrama, teknik dan materi psikodrama, alat penunjang, penentuan waktu serta penentuan ruang. Modul psikodrama ini dibagi ke dalam 4 sesi yang dilakukan atas dasar pertimbangan penurunan teori self-esteem (Coopersmith, 1967) yang menyatakan bahwa 4 area (school, peers, keluarga (orang tua), dan personal interest ) merupakan area yang sangat berpengaruh dalam pembentukan self-esteem, sehingga diangkat sebagai penentu sesi dalam psikodrama. Hal ini juga diperkuat dengan 
pertimbangan penelitian mengenai psikodrama yang sudah dilakukan sebelumnya, bahwa psikodrama dapat memberikan manfaat atau perubahan yang lebih maksimal dan permanen saat diberikan lebih dari 3-4 kali sesi pertemuan (Parahita, 2019)

Dalam penyusunan modul di setiap sesinya selalu mengacu pada tahapan psikodrama menurut J.L Moreno (1889-1974) yang terdiri dari lingkaran pembuka, warming up, action, integrasi-debrief, dan lingkaran penutup. Teknik yang digunakan dalam modul psikodrama ini, disesuaikan dengan tujuan yang ingin dicapai untuk meningkatkan self-esteem dalam setiap tahapannya dan disesuaikan dengan tujuan dasar dari setiap tahapan psikodrama menurut J.L Moreno (1889-1974). Teknik yang digunakan dalam modul psikodrama ini juga disesuaikan dengan karakteristik dari setiap sesi pertemuan.

Materi dalam modul ini disusun berdasarkan karakteristik psikodrama, yaitu spontanitas anak dalam mengangkat ide cerita dan keterlibatan dalam berperan. Alternatif materi dalam tahapan action dipersiapkan dengan mempertimbangkan karakteristik anak SLD dengan self-esteem rendah yang mungkin memiliki kesulitan untuk mengungkapkan ide cerita. Materi yang disusun dalam setiap tahapan diturunkan berdasarkan gambaran self-esteem rendah dan disesuaikan dengan karakteristik khas dari anak dengan specific learning disorder. Alat penunjang yang dipersiapkan dalam adalah kamera, voice recorder, kain 20 warna, boneka, sarung, kostum orang tua, tas, sepatu, mainan profesi, alat musik, bola, kartu, lagu dan video profesi, stiker untuk nama peserta, alat tulis, snack dan makan siang.

Uji coba rancangan intervensi psikodrama ini terdiri dari seorang sutradara dan empat orang observer. Sutradara memiliki tugas untuk memberikan uji coba rancangan intervensi psikodrama sesuai dengan rancangan modul yang telah disusun oleh peneliti. Sutradara adalah psikolog (praktisi psikodrama) yang telah bersertifikasi atau berpengalaman di bidang psikodrama, telah berpengalaman dalam memfasilitasi berbagai psikodrama khususnya bagi anak dan remaja, serta memahami isi modul sehingga dapat menyampaikan materi dengan kemasan menarik di setiap sesinya. Observer bertugas untuk mengamati peserta dan sutradara selama uji coba rancangan modul intervensi berlangsung. Observer yang dipilih memiliki kualifikasi yaitu sarjana psikologi, memiliki pengetahuan, pengalaman dalam melakukan observasi (pengamatan), dan pernah mengikuti atau mengetahui mengenai metode psikodrama.

Pada tahap Evaluation Instrument peneliti menentukan dan menyusun tools yang dapat digunakan sebagai bahan evaluasi menggunakan kuesioner, observasi dan interview. Pengambilan data disini dilakukan dengan observasi, wawancara, pengisian kuesioner serta 
catatan arsip orang tua dan guru. Panduan alat ukur self-esteem Coopersmith (1997) yang digunakan berdasarkan alat ukur yang sudah dibuat oleh Azwar (2007), diperoleh berupa versi bahasa Indonesia Self-esteem Inventory (CSI) dari Coopersmith (1967), dengan konsistensi internal Cronbach $\alpha=.714$.

Pada tahap uji validitas dilakukan dengan menguji kelayakan modul oleh expert judgement. Adapun kriteria expert judgement adalah seorang psikolog yang berperan sebagai dosen atau seorang akademisi yang pernah membimbing dalam penyusunan tugas akhir dan seorang Psikolog yang sudah banyak berkecimpung dalam penggunaan psikodrama sebagai salah satu intervensi dalam penanganan masalah kesehatan mental. Para ahli memberikan masukan yang beragam dalam penyempurnaan rancangan modul. Masukan digunakan untuk perbaikan modul mencakup : tampilan modul, isi dan teknik yang relevan untuk pencapaian tujuan modul, waktu, alat penunjang dan penggunaan bahasa.

\section{Tahap Studi II}

Penelitian dalam studi II merupakan tahapan uji coba modul intervensi psikodrama yang terdiri dari pelaksanaan uji coba, evaluasi hasil uji coba, dan revisi program psikodrama yang sudah di uji coba. Pendekatan yang digunakan pada penelitian adalah quasi eksperimen. Desain penelitian yang digunakan adalah small design, one group pre test-post test. Uji coba rancangan modul memerlukan waktu selama 120-180 menit dalam setiap pertemuan. Tempat pelaksanaan kegiatan dipilih dengan kriteria standar kebutuhan pelaksanaan psikodrama. Dengan ruangan yang cukup luas, sirkulasi udara yang baik, pencahayaan yang cukup (Dzokic, 2009).

Teknik sampling yang digunakan dalam penelitian ini adalah purposive sampling techniques. Adapun kriteria subjek dalam penelitian ini adalah Anak usia 9-12 tahun, memiliki jenis kelamin perempuan dan laki-laki, serta memiliki self-esteem yang rendah sesuai dengan kriteria alat ukur SEI (Self-esteem Inventory, Coopersmith, 1967). Partisipan yang digunakan dalam penelitian ini berjumlah 9 anak, merupakan vulnerable participant yaitu anak-anak yang berusia di bawah 12 tahun. Informed consent tidak langsung diberikan kepada anak melainkan terlebih dahulu diberikan kepada orang tua atau wali yang bertanggung jawab terhadap anak. Perolehan skor awal self-esteem diperoleh melalui tahapan pretest yang dilakukan sebelum tahapan uji coba. Self-esteem posttest dilakukan sebanyak 3 kali dalam jarak waktu pengambilan data posttest 1, 2, dan 3 masing-masing berjarak 2 minggu. Hal ini dilakukan dengan pertimbangan ingin melihat konsistensi dampak treatment psikodrama. 
Dalam penelitian ini terdapat dua sumber data yang diperoleh. Data kualitatif diperoleh dengan mencermati perubahan rancangan modul yang terjadi di tahap studi I dalam penelitian berdasarkan masukan expert judgement. Tahap studi II diperoleh data dengan mencermati perubahan modul berdasarkan proses kegiatan uji coba psikodrama dan evaluasi peserta. Data interview dan observasi digunakan sebagai data sekunder untuk memperkuat data perubahan modul psikodrama. Analisis data sebagai data sekunder, diperoleh dari skor skala self-esteem dengan menggunakan Wilcoxon T Test yang diolah dengan bantuan aplikasi pengolahan data statistik SPSS for MS Windows version 25.

\section{HASIL DAN PEMBAHASAN}

Pada studi tahap I, expert judgement memberikan masukan dalam penyempurnaan rancangan modul psikodrama untuk meningkatkan self-esteem rendah pada anak dengan specific learning disorder usia 9-12 tahun

Tabel 1.

Hasil Uji Kelayakan Rancangan Modul Intervensi Psikodrama

\begin{tabular}{|c|c|c|c|c|}
\hline \multirow{2}{*}{$\begin{array}{l}\text { Aspek } \\
\text { Penilaian }\end{array}$} & \multicolumn{3}{|l|}{ Masukan } & \multirow[t]{2}{*}{ Perbaikan } \\
\hline & Ahli 1 & Ahli 2 & Ahli 3 & \\
\hline $\begin{array}{l}\text { Tampilan } \\
\text { Modul }\end{array}$ & $\begin{array}{l}\text { Masih perlu dibuat } \\
\text { menjadi suatu } \\
\text { kesatuan yang utuh } \\
\text { dalam keseluruhan } \\
\text { prosesnya. }\end{array}$ & $\begin{array}{l}\text { Tampilannya sudah } \\
\text { cukup baik dan } \\
\text { menarik untuk anak. }\end{array}$ & $\begin{array}{l}\text { Dibuat lebih } \\
\text { konkret } \\
\text { gambaran } \\
\text { kegiatannya } \\
\text { sehingga } \\
\text { pembaca akan } \\
\text { lebih memahami } \\
\text { prosesnya }\end{array}$ & $\begin{array}{l}\text { Alurnya dibuat lebih } \\
\text { menyatu dari sesi } 1 \\
\text { hingga akhir dan } \\
\text { dibuat lebih konkret } \\
\text { sesuai dengan } \\
\text { pengalaman yang } \\
\text { dihadapi dalam } \\
\text { keseharian anak }\end{array}$ \\
\hline Materi & $\begin{array}{l}\text { Dibuat lebih beragam } \\
\text { lagi materinya, } \\
\text { terutama dalam sesi } \\
\text { warming up }\end{array}$ & $\begin{array}{l}\text { Perlu penambahan } \\
\text { alternative cerita di } \\
\text { tahapan action untuk } \\
\text { mempermudah anak } \\
\text { dalam prosesnya. } \\
\text { Membuat } \\
\text { pertimbangan dengan } \\
\text { melihat karakteristik } \\
\text { anak yang memiliki } \\
\text { self-esteem rendah. }\end{array}$ & $\begin{array}{l}\text { Coba } \\
\text { pertimbangkan } \\
\text { materi pilihan } \\
\text { pada warming } \\
\text { up untuk sesi } 1 \\
\text { dan sesi } 3\end{array}$ & $\begin{array}{l}\text { 1. Materi dalam } \\
\text { warming up di } \\
\text { perbanyak. } \\
\text { 2. Materi pilihan } \\
\text { sosiometri lokogram } \\
\text { pada sesi } 1 \text { dan } 3 \\
\text { sudah diperbaiki } \\
\text { dengan pilihan tidak } \\
\text { membingungkan } \\
\text { dalam menentukan } \\
\text { pilihan. } \\
\text { 3. Alternative cerita } \\
\text { ditambahkan dengan } \\
\text { membuat } 3 \\
\text { kemungkinan yang } \\
\text { dialami anak dengan } \\
\text { self-esteem rendah. }\end{array}$ \\
\hline Teknik & $\begin{array}{l}\text { Perlu adanya } \\
\text { pertimbangan dari } \\
\text { teknik yang } \\
\text { digunakan. Sesuaikan }\end{array}$ & $\begin{array}{l}\text { Perlu dibuatkan } \\
\text { glossary agar } \\
\text { mempermudah } \\
\text { pembaca dalam }\end{array}$ & $\begin{array}{l}\text { Perlu dibuat } \\
\text { penjelasan yang } \\
\text { lebih konkret }\end{array}$ & $\begin{array}{l}\text { 1. Teknik mirroring } \\
\text { dan role reversal } \\
\text { dihilangkan dengan } \\
\text { melihat karakteristik }\end{array}$ \\
\hline
\end{tabular}




\begin{tabular}{|c|c|c|c|}
\hline & $\begin{array}{l}\text { lagi dengan } \\
\text { karakteristik anak dan } \\
\text { tujuan. Terutama } \\
\text { penggunaan teknik } \\
\text { mirroring, dan role } \\
\text { reversal. }\end{array}$ & $\begin{array}{l}\text { memahami teknik- } \\
\text { tekniknya. }\end{array}$ & $\begin{array}{l}\text { anak usia } 9-12 \\
\text { tahun agak sulit } \\
\text { untuk menggunakan } \\
\text { teknik tersebut, } \\
\text { sehingga lebih } \\
\text { diperbanyak dengan } \\
\text { teknik sculpture, role } \\
\text { play dan dilakukan } \\
\text { penambahan teknik } \\
\text { amplifying. } \\
\text { 2. Untuk } \\
\text { mempermudah } \\
\text { memahami makna } \\
\text { dari setiap teknik, } \\
\text { dibuatkan glossary } \\
\text { terkait kata-kata yang } \\
\text { ada di dalam modul } \\
\end{array}$ \\
\hline Tujuan & \multicolumn{2}{|c|}{$\begin{array}{l}\text { Tujuan dari setiap tahapan dan teknik perlu di spesifikan lagi di } \\
\text { setiap tahapannya agar lebih tergambar. }\end{array}$} & $\begin{array}{l}\text { Tujuan sudah dibuat } \\
\text { lebih spesifik di } \\
\text { setiap tahapannya }\end{array}$ \\
\hline Waktu & $\begin{array}{l}\text { Pertimbangkan waktu } \\
\text { keseluruhan dengan } \\
\text { kondisi kelelahan } \\
\text { anak, perhatikan } \\
\text { persediaan makanan } \\
\text { ringan dan makanan } \\
\text { berat untuk } \\
\text { menunjang kondisi } \\
\text { anak }\end{array}$ & $\begin{array}{l}\text { Perlu dipertimbangkan waktu di setiap } \\
\text { tahapannya. Terutama pada tahap } \\
\text { lingkaran pembuka di sesi } 1 \text { perlu } \\
\text { ditambahkan waktu karena ada } \\
\text { pertimbangan penyesuaian dengan } \\
\text { karakteristik anak dengan self-esteem } \\
\text { yang rendah. }\end{array}$ & $\begin{array}{l}\text { Penambahan waktu di } \\
\text { warming up sudah } \\
\text { ditambahkan dengan } \\
\text { mempertimbangkan } \\
\text { karakteristik anak } \\
\text { dengan self-esteem } \\
\text { rendah. Terkait } \\
\text { dengan antisipasi } \\
\text { kelelahan anak } \\
\text { dengan waktu yang } \\
\text { digunakan secara } \\
\text { keseluruhan, peneliti } \\
\text { melakukan antisipasi } \\
\text { terkait kelelahan }\end{array}$ \\
\hline
\end{tabular}

Pada studi tahap II, diperoleh data 5 subjek yang memiliki skor self-esteem yang berada pada kategori rendah. Self-esteem setiap individu dipengaruhi dari 4 area kehidupan, yaitu area orang tua, teman, sekolah dan diri sendiri. Peneliti juga melakukan tahapan interview untuk menggali data mengenai bentuk perilaku self-esteem rendah pada setiap subjek dan digunakan sebagai sumber informasi awal sutradara sebelum memainkan psikodrama.

Tabel 2.

Skor Self-esteem Pretest dan Posttest

\begin{tabular}{llllllllc}
\hline \multirow{2}{*}{ Subjek } & \multicolumn{2}{c}{ Pre Test } & \multicolumn{2}{c}{ Post Test I } & \multicolumn{2}{c}{ Post Test II } & \multicolumn{2}{c}{ Post Test III } \\
\cline { 2 - 9 } & Skor & Kategori & Skor & Kategori & Skor & Kategori & Skor & Kategori \\
\hline 1 & 42 & Rendah & 68 & Tinggi & 60 & Tinggi & 60 & Tinggi \\
\hline 2 & 30 & Rendah & 50 & Rendah & 52 & Rendah & 50 & Rendah \\
\hline 3 & 18 & Rendah & 22 & Rendah & 26 & Rendah & 28 & Rendah \\
\hline 4 & 40 & Rendah & 62 & Tinggi & 74 & Tinggi & 80 & Tinggi \\
\hline 5 & 52 & Rendah & 76 & Tinggi & 84 & Tinggi & 90 & Tinggi \\
\hline
\end{tabular}


Berdasarkan hasil pretest diperoleh 5 subjek yang berada pada kategori rendah, 3 subjek memiliki skor yang rendah pada area orang tua, 2 subjek memiliki skor rendah pada area diri, dan 5 subjek rata-rata memiliki skor rendah pada area teman dan sekolah. Data ini digunakan oleh peneliti sebagai data awal dalam melakukan proses uji coba. Subjek yang memiliki skor rendah pada area tertentu akan memiliki kesempatan untuk mendapatkan perhatian lebih pada setiap sesinya.

Berdasarkan hasil data posttest yang sudah dilakukan, dari 5 subjek terdapat perbedaan skor dari pengambilan data posttest 1 hingga 3. Hampir keempat subjek mengalami peningkatan skor secara keseluruhan. Hanya subjek 1 yang mengalami penurunan skor dari pretest I-III dan subjek 2 sempat mengalami kenaikan pada pretest ke 2 dan kembali pada skor pretest I pada pretest yang ke III. Hanya saja secara keseluruhan semua subjek masih berada pada kategori skor yang sama, 3 subjek berada pada kategori tinggi dan 2 subjek berada pada kategori rendah.

Tabel 3.

Hasil Evaluasi Modul Psikodrama

\begin{tabular}{llllll}
\hline Aspek & Skor & Penilaian & Aspek & Skor & Penilaian \\
\hline Tampilan Modul & 4 & Sangat Baik & Alat penunjang & 4 & Sangat Baik \\
\hline Isi Materi & 4 & Sangat Baik & Penggunaan bahasa & 3 & Baik \\
\hline Teknik & 4 & Sangat Baik & Penampilan Sutradara & 3 & Baik \\
\hline Tujuan & 4 & Sangat Baik & Pemahaman anak & 4 & Sangat Baik \\
\hline Waktu & 3 & Baik & Tempat & 3 & Baik \\
\hline
\end{tabular}

Hasil evaluasi uji coba rancangan modul intervensi psikodrama ini dilakukan oleh 5 peserta uji coba dan dilengkapi dengan evaluasi subjektif berupa manfaat yang dirasakan oleh para subjek uji coba rancangan modul setelah mengikuti psikodrama melalui metode interview kepada subjek saat selesai mengisi skala self-esteem sebagai post test. Evaluasi meliputi dua hal yaitu evaluasi pelaksanaan uji coba psikodrama dan penilaian mencakup penyampaian materi, alat yang digunakan, isi modul, manfaat modul, dan waktu.

Berdasarkan penilaian yang diperoleh, anak mengatakan bahwa penyampaian materi sudah jelas diberikan dan mudah dipahami, isi kegiatannya menarik dan tidak membuat bosan karena berbeda-beda tema yang diangkat di setiap sesi kegiatan. Alat yang digunakan beraneka ragam, menarik untuk dimainkan serta membuat anak lebih mudah untuk memainkan peran. Waktu yang digunakan juga cukup karena anak tidak merasa kelelahan karena ada waktu istirahat di setiap pergantian tahapan psikodrama. Anak juga merasakan adanya manfaat positif setelah mengikuti kegiatan, dimana anak merasa bisa mengeluarkan perasaan yang selama ini 
dirasakan, mendapatkan pemahaman baru mengenai diri, mencoba untuk berani dan memiliki teman baru.

Tabel 4.

Hasil Analisis Data

\begin{tabular}{lllll}
\hline Uji & Hasil & & Kesimpulan \\
\cline { 2 - 4 } & Mean & $\boldsymbol{Z}$ & Asymp. Sig & \\
\hline Uji Wilcoxon & 3,00 & $-2,032^{b}$ &, 042 & Signifikan artinya psikodrama \\
Pretest-Posttest & & & $P<0,05$ & meningkatkan self-esteem \\
\hline
\end{tabular}

Pada proses pengolahan data, analisis kuantitatif dalam penelitian ini dilakukan dengan membandingkan perubahan skor self-esteem pada seluruh siswa berdasarkan hasil pengukuran pretest dan posttest menggunakan skala self-esteem. Berdasarkan hasil uji wilcoxon pada pengukuran pretest dan posttest diperoleh hasil Z skor $=-2,032$ dan Sig (2-tailed) sebesar 0,$04 ; \mathrm{P}<0.05$. Hasil tersebut menunjukkan ada perbedaan yang signifikan.

Tabel 4.

Hasil Revisi Uji Coba Modul Psikodrama

\begin{tabular}{|c|c|}
\hline Kondisi peserta dan modul & Perbaikan Modul \\
\hline \multirow[t]{3}{*}{$\begin{array}{l}\text { Di sesi } 1 \text { dalam tahapan lingkaran } \\
\text { pembuka peserta masih kesulitan untuk } \\
\text { bisa memperkenalkan diri }\end{array}$} & $\begin{array}{l}\text { Diberikan tambahan materi permainan yang lebih beragam } \\
\text { agar peserta bisa waktu yang lebih lama untuk bisa } \\
\text { memperkenalkan diri }\end{array}$ \\
\hline & $\begin{array}{l}\text { Materi permainan diawali dengan pemberian contoh konkrit } \\
\text { dan alternatif pilihan contoh agar peserta lebih mudah untuk } \\
\text { mencoba }\end{array}$ \\
\hline & $\begin{array}{l}\text { Setiap materi akan dilakukan dengan teknik secara bersama- } \\
\text { sama antar peserta }\end{array}$ \\
\hline Ada anak yang mogok di awal kegiatan & $\begin{array}{l}\text { Penambahan catatan penanganan anak yang mogok untuk } \\
\text { tetap terlibat dalam kegiatan dengan tetap berada di dalam } \\
\text { ruangan sampai peserta mau ikut terlibat }\end{array}$ \\
\hline \multirow[t]{2}{*}{$\begin{array}{l}\text { Anak masih malu-malu dan belum siap } \\
\text { masuk ke tahapan action }\end{array}$} & $\begin{array}{l}\text { Materi dalam warming up diperbanyak jumlahnya agar lebih } \\
\text { memiliki variasi pilihan untuk peserta }\end{array}$ \\
\hline & $\begin{array}{l}\text { Proses pengulangan pada tahap warming up di sesi } \\
\text { selanjutnya dengan mengulang materi yang sudah dilakukan } \\
\text { pada pertemuan sebelumnya }\end{array}$ \\
\hline $\begin{array}{l}\text { Kondisi anak terlihat kurang } \\
\text { bersemangat dan kelelahan }\end{array}$ & $\begin{array}{l}\text { Waktu istirahat bisa lebih fleksibel untuk mengurangi faktor } \\
\text { kelelahan pada anak. Waktu istirahat bisa dilakukan di sela } \\
\text { setiap pergantian tahap psikodrama. }\end{array}$ \\
\hline $\begin{array}{l}\text { Peserta kesulitan dalam mengungkapkan } \\
\text { pendapat dalam tahap integrasi-debrief }\end{array}$ & $\begin{array}{l}\text { Teknik sosiometri - spektogram ditambahkan dalam sesi } \\
\text { untuk melihat penilaian peserta terkait kegiatan yang } \\
\text { dilakukan dan menjadi data pada pertemuan selanjutnya }\end{array}$ \\
\hline $\begin{array}{l}\text { Anak lebih antusias ketika banyak alat } \\
\text { penunjang yang digunakan }\end{array}$ & $\begin{array}{l}\text { Penambahan alat penunjang dilakukan pada sesi ke } 3 \text { dan } 4 . \\
\text { Hal ini diberikan agar anak lebih menghayati dan lebih senang } \\
\text { ketika memainkan adegan cerita yang dirasa lebih nyata ketika } \\
\text { menggunakan alat beragam }\end{array}$ \\
\hline $\begin{array}{l}\text { Karakteristik anak lebih mudah } \\
\text { mengingat sesaat setelah kejadian } \\
\text { berlangsung }\end{array}$ & $\begin{array}{l}\text { Tahapan debrief dapat dilakukan lebih fleksibel. Fleksibel } \\
\text { yang dimaksud adalah debrief yang diberikan bisa disesuaikan } \\
\text { dengan gaya masing-masing sutradara hanya tetap saja point } \\
\text { penyampaian mengacu pada ketentuan modul. Hal ini melihat }\end{array}$ \\
\hline
\end{tabular}




\begin{tabular}{ll}
\hline & $\begin{array}{l}\text { kondisi peserta yang lebih mudah mengingat pengalaman } \\
\text { yang baru saja dimainkan dan lebih mudah untuk } \\
\text { memasukkan pemahaman yang ingin dimunculkan dari setiap } \\
\text { adegan yang dimainkan }\end{array}$ \\
\hline Waktu & Waktu yang digunakan dalam kegiatan dapat disesuaikan \\
& dengan kondisi masing-masing peserta dalam setiap kegiatan. \\
& Modul akan tetap diberikan waktu maksimal namun dalam \\
& pelaksanaannya dapat disesuaikan kembali dengan kondisi \\
& peserta, terutama pada tahap warming up. \\
\hline Bahasa & Bahasa yang digunakan disesuaikan dengan karakteristik dari \\
& masing-masing sutradara. Hanya saja tetap poin utama yang \\
& perlu diperhatikan adalah tujuan yang ingin dicapai dalam \\
& setiap tahapan. \\
\hline
\end{tabular}

Pada studi tahap I, expert judgement menyarankan berkaitan tampilan modul. Materi dibuat menjadi suatu kesatuan agar modul memiliki keterkaitan dari setiap sesi yang dilakukan. Materi yang dibuat disesuaikan dengan pengalaman yang dialami oleh anak dalam kesehariannya. Hal ini dilakukan dengan memberikan lebih banyak alternatif cerita dengan kondisi yang sering dialami oleh anak berdasarkan hasil data yang diperoleh. Proses ini dilakukan untuk melihat lebih mendalam kebutuhan, faktor yang berpengaruh dan masalah yang sesuai dengan kondisi anak, yang kemudian disesuaikan dengan rancangan intervensi agar tercapai tujuan lebih maksimal (Morrison, 2012).

Warming up bertujuan untuk membantu anak baru dan pemalu memulai percakapan dengan mengembangkan keterampilan komunikasi dan membangun tim, memecah kebiasaan antara anak, mempromosikan rasa percaya dan persahabatan di antara mereka, mendorong, dan mempersiapkan mereka untuk belajar dengan merangsang pikiran dan atau tubuh mereka (Pillai, 2007). Dalam modul, materi pada tahap warming up dibuat lebih banyak jumlah kegiatannya. Hal ini dilakukan atas dasar pertimbangan tujuan dari tahapan warming up, yaitu untuk membangun atmosfer akan kepercayaan dan kenyamanan (Wilkins, 1999), sehingga dengan adanya penambahan materi anak akan lebih memiliki keleluasaan mencoba dan memiliki lebih banyak kesempatan untuk membangun kepercayaan dan rasa nyaman. Di tahapan action, penambahan alternatif cerita juga ikut serta diberikan penambahan. Hal ini dilakukan atas dasar pertimbangan karakteristik anak yang lebih banyak diam dan sulit menyampaikan pendapat, sehingga mempermudah anak dengan adanya alternatif cerita yang lebih banyak dan dibuat lebih mendetail (Gundon, 2010).

Pemilihan teknik mirroring dan role reversal dinilai oleh ahli kurang tepat jika digunakan oleh anak usia 9-12 tahun. Hal ini disebabkan oleh dasar pemikiran kemampuan kognitif anak usia 9-12 tahun masih berada pada tahap konkret operasional. Moreno (2009) 
menjelaskan di dalam teknik mirroring protagonis diminta untuk keluar dan melihat adegan sebagai cermin diri dan dalam teknik role reversal protagonis dan rekannya akan menjadi diri yang sama di dimensi waktu yang berbeda. Dengan penggunaan teknik mirroring dan role reversal akan membutuhkan cara berpikir yang lebih abstrak, sehingga teknik ini dihilangkan dan diganti dengan teknik yang lebih mudah untuk anak yaitu future projection. Dalam teknik ini peserta hanya diminta untuk memainkan adegan yang sesuai dengan cita-citanya, hal ini memudahkan peserta dan melakukan imajinasi untuk memainkan cerita. Ditambah lagi dengan penambahan teknik baru yaitu amplifying untuk membuat peserta merasakan pengalaman yang lebih besar dari sebelumnya dengan bantuan sutradara.

Penentuan waktu juga menjadi hal yang diperhatikan oleh ahli, perlu adanya antisipasi terutama dengan perkiraan waktu keseluruhan di setiap sesinya yang memakan waktu cukup lama yaitu 240 menit, hal ini tentu akan berpengaruh pada kondisi anak. Kemampuan mempertahankan perhatian pada anak akhir adalah 30-60 menit (Berk, 2003; Teeter, 1998). Oleh karena itu, peneliti melakukan antisipasi untuk mengurangi faktor kelelahan anak karena rentang perhatian anak hanya 30-60 menit, peneliti menyiapkan waktu istirahat dan makanan di setiap pergantian tahapan psikodrama untuk mengurangi faktor kelelahan anak serta menjaga anak agar tetap bisa fokus pada saat kegiatan.

Ahli juga menyarankan bahwa bahasa yang digunakan seharusnya dapat lebih fleksibel dalam penggunaannya. Hal ini dipertimbangkan gaya dari setiap sutradara akan berbeda dan modul dalam hal ini menjadi acuan dalam pelaksanaan psikodrama, sehingga fleksibilitas dalam penggunaannya masih dimungkinkan. Fleksibel yang dimaksud dalam modul ini adalah sutradara tetap mengacu pada hal penting yang ada di dalam modul seperti tujuan ataupun nilai yang ingin dicapai, sehingga point penting yang ada di dalam modul tetap tersampaikan dengan gaya bahasa yang disesuaikan oleh sutradara.

Pada studi tahap I, berdasarkan uji coba yang sudah dilakukan terdapat sedikit perubahan terkait dengan modul yang digunakan disesuaikan dengan spontanitas dengan respon yang diberikan oleh peserta dan disesuaikan dengan tujuan dan kondisi peserta saat menjalani kegiatan psikodrama dengan tetap menggunakan kerangka modul yang sudah dibuat. Spontanitas ini didasari dengan dinamika peserta dalam memberikan cerita, namun ketika spontanitas tidak bisa muncul, sutradara akan mengarahkan peserta untuk dapat melakukan kegiatan sesuai dengan modul yang digunakan. Cara membawakan kegiatan akan kembali 
kepada masing-masing sutradara. Hanya saja poin utama modul tetap menjadi acuan penting yang harus digunakan oleh sutradara.

Rancangan modul intervensi psikodrama yang sudah dilakukan menunjukkan adanya perubahan setelah dilakukannya uji coba. Setiap tahapan yang dilakukan dalam psikodrama ini selalu dikaitkan dengan prinsip inti psikodrama seperti yang didalilkan oleh Moreno (1998) adalah teori "spontanitas-kreativitas". Cara terbaik bagi seseorang untuk merespons secara kreatif terhadap suatu situasi adalah melalui spontanitas yang tercermin dari kesiapan untuk berimprovisasi dan merespons pada saat itu (Moreno dalam Dzokic, 2009). Spontanitas dalam hal ini adalah proses kegiatan yang berlangsung tetap dilakukan sesuai dengan modul yang sudah dibuat dan respon anak menjadi hal yang penting dalam proses pelaksanaannya. Respon anak yang spontan ini membuat modul psikodrama yang digunakan dalam uji coba mengalami adanya perubahan. Perubahan yang dimaksud adalah adanya penambahan teknik dan materi dari modul yang sudah dibuat sebelumnya, penambahan teknik penanganan anak, perubahan waktu, perubahan bahasa dari modul yang sudah dibuat.

Tahap lingkaran pembuka berisi tentang pengenalan antar peserta dengan tim peneliti sebagai tahap pertama dalam psikodrama yaitu persiapan-persiapan sebelum masuk dalam sesi psikodrama (Moreno dalam Dzokic, 2009). Berdasarkan hasil uji coba, pada rancangan modul proses perkenalan anak hanya dilakukan dengan 1 materi ice breaking, yaitu memperkenalkan dengan menunjukkan gaya yang unik. Hanya saja dengan kondisi subjek yang memiliki karakteristik self-esteem rendah, membutuhkan waktu bagi subjek untuk bisa menampilkan dirinya di suatu lingkungan yang baru. Dalam pelaksanaan uji coba, dilakukan penambahan pada tahap lingkaran pembuka materi ice breaking. Terutama ketika mereka diharuskan untuk memulai suatu kegiatan, semua anak tidak ada yang berani untuk mengawali kegiatan perkenalan, sehingga perkenalan dilakukan secara "bersama-sama". Dover (2004) mengatakan ice breaking digunakan sebagai "kegiatan interaksi" yang dapat digunakan untuk membantu peserta untuk belajar berbicara dengan mudah dan menyenangkan, serta mengembangkan lingkungan yang dapat menguras perasaan cemas, "memecahkan kebekuan" antara peserta dengan kegiatan yang menyenangkan. Dengan adanya penambahan materi, membuat anak memiliki waktu lebih lama untuk terbiasa berada di lingkungan baru, anak lebih siap untuk mengungkapkan dirinya di dalam kelompok, anak dapat dengan nyaman untuk saling mengenal satu sama lain dan membuat pola yang terbuka. Tujuan ini dapat dicapai oleh anak 
yang memiliki self-esteem rendah pada tahap ini ketika semua anak melakukannya bersamasama.

Pada tahapan warming up materi yang diberikan dirasa kurang membangun peserta untuk siap masuk dalam tahapan selanjutnya karena terlalu sedikitnya materi yang dibuat. Dengan karakteristik yang dimiliki subjek, membutuhkan waktu yang lebih lama untuk beradaptasi di suatu lingkungan yang baru (Branden, 1994; Gundon, 2010). Perbaikan yang dilakukan adalah dengan melakukan penambahan materi dalam tahapan warming up terutama pada teknik sculpture. Proses warming up harus berkembang dari pinggiran menuju pusat, kegiatan awal disesuaikan dengan situasi yang lebih dangkal secara emosional untuk secara bertahap mencapai pengalaman emosional yang lebih dalam, lebih intens, sehingga protagonis siap memasuki tahapan selanjutnya yaitu action (Moreno dalam Dzokic, 2009). Dengan adanya penambahan materi, anak lebih memiliki waktu untuk nyaman berada di lingkungan yang baru dan siap memasuki tahapan selanjutnya. Hal ini diperkuat dengan pertimbangan bahwa warming up menjadi tahapan yang penting untuk mengembangkan hubungan dan keterlibatan dengan anggota individu dan dengan kelompok sebagai suatu sistem, serta untuk mengembangkan kohesi kelompok dan dasar kerja saling percaya antara anggota (Antony Williams, 1991).

Selain itu pola pengulangan menjadi suatu hal yang penting dalam psikodrama terutama pada tahapan ini (Moreno dalam Dzokic, 2009). Anak akan memiliki proses belajar karena adanya pengulangan serta adanya rasa senang dan bangga ketika mengulang suatu kegiatan yang sudah berhasil dilakukan sebelumnya. Hal tersebut akan lebih menguatkan pengalaman yang sudah dirasakan oleh anak, sehingga ada penambahan catatan untuk melakukan pengulangan materi sesi sebelumnya di sesi selanjutnya. Proses pengulangan ini bisa dilakukan juga dengan memunculkan pengulangan teknik namun dengan materi yang berbeda membuat anak merasakan pengalaman yang berbeda. Hal ini terlihat ketika anak menjadi lebih bersemangat dan mau mencoba tanpa membutuhkan waktu yang lama di pertemuan kedua.

Pada tahap action berdasarkan hasil uji coba, penambahan alat penunjang masih diperlukan. Alat penunjang yang ditambahkan yaitu kartu emosi, alat musik, boneka jari, alat gambar, lagu, dan video profesi. Penambahan alat ini disesuaikan dengan situasi cerita yang akan dimainkan anak. Hal ini dilakukan atas dasar pertimbangan alat penunjang digunakan sebagai suatu alat yang dapat diserap oleh mata dan telinga dengan tujuan agar proses belajar mengajar siswa lebih efektif dan efisien (Sudjana, 2002:59). Alat penunjang akan membuat 
anak mudah dalam memvisualisasikan ide-ide cerita yang sedang dimainkan. Media yang berkaitan dengan gambar dapat membantu memvisualisasikan sesuatu yang bersifat abstrak menurut Ulfarina (2010). Semakin banyak alat penunjang yang digunakan dan disesuaikan dengan tema cerita yang diperankan, membuat kegiatan psikodrama lebih menarik, mengarahkan perhatian anak, serta membantu pengertian anak dalam memahami cerita. Anak terlihat lebih mendalami cerita dan bisa melakukan inisiatif yang lebih beragam dalam memainkan ceritanya.

Tahap integrasi-debrief ini diperuntukkan bagi peserta agar lebih memahami dan mampu di dalam mengelola diri dan mampu berpikir dari sudut pandang lain (Moreno dalam Dzokic, 2009). Pada setiap sesi juga diakhiri dengan sharing yang bertujuan untuk saling memberi dukungan antar peserta, melatih kemampuan mengungkapkan diri, melatih memahami dan mengelola konflik pada dirinya. Pada sesi ini anak mendapatkan umpan balik dari teman maupun sutradara sehingga anak dapat menyelaraskan apa yang sudah dilakukan pada setiap sesinya. Pada tahap ini anak dibantu untuk mendapatkan pemahaman baru mengenai dirinya, anak akan merasakan keberhasilan dari setiap peran yang dimainkan sehingga anak lebih menghargai pencapaian dan dapat melatih kemampuan anak dalam berkomunikasi.

Berdasarkan hasil uji coba, tahapan integrasi dapat dilakukan dengan suasana yang nyaman agar anak dapat lebih menerima informasi yang diberikan. Fleksibilitas dalam melakukan tahapan ini diperlukan, tahapan ini tidak harus dilakukan setelah semua tahapan kegiatan selesai, namun bisa dilakukan sesaat setelah anak selesai melakukan suatu peran dalam sebuah cerita. Pada tahapan ini juga bisa dilakukan teknik sosiometri-spektogram sehingga sutradara mendapatkan data penilaian secara langsung. Penilaian secara langsung digunakanan agar memudahkan anak dalam proses evaluasi atau penilaian terhadap diri serta anak dapat langsung mendapatkan masukan atas hasil yang sudah dilakukan.

\section{SIMPULAN}

Pada penelitian ini peneliti berfokus pada hasil uji coba modul psikodrama untuk meningkatkan self-esteem anak usia 9-12 tahun yang mengalami kesulitan belajar. Berdasarkan hasil uji coba rancangan modul yang sudah dilakukan terdapat perbaikan yang dilakukan dalam modul psikodrama pada tahapan lingkaran pembuka, warming up, action, integrasi-debrief dan lingkaran penutup. Perbaikan dilakukan dengan memberikan banyak penambahan materi, 
teknik dan alat penunjang di tahapan lingkaran pembuka, warming up, action dan integrasidebrief. Proses pengulangan menjadi suatu hal yang penting karena dapat menunjang proses pembelajaran kepada anak di dalam tahapan warming up. Waktu pelaksanaan terdapat perubahan secara keseluruhan dimana menjadi lebih singkat dengan pertimbangan kondisi peserta. Fleksibilitas dalam psikodrama diperlukan terkait penggunaan teknik dan bahasa yang digunakan dalam proses psikodrama yang dilakukan. Adapun keterbatasan dalam penelitian ini, proses pengambilan data pretest dalam penelitian ini hanya dilakukan 1 kali pengambilan data, sedangkan pengambilan data hasil postest dilakukan 3 kali. Untuk mendukung data baseline peserta yang lebih akurat dan konsisten sebelum diberikannya intervensi, lebih baik pengambilan data pretest dilakukan juga sebanyak 3 kali. Selain itu antisipasi yang terkait dengan jadwal pertemuan perlu dibuat waktu pengganti untuk kondisi tertentu jika terjadi suatu hal pada jadwal awal yang sudah ditentukan dalam penelitian.

\section{DAFTAR PUSTAKA}

American Psychiatric Association. (2013). Diagnostic and statistical manual of mental disorders (5th ed.). Arlington, VA: American Psychiatric Association.

Bateman, A., Bolton, R., \& Fonagy, P. (2013). Antisocial personality disorder: A mentalizing framework. FOCUS: The Journal of Lifelong Learning in Psychiatry, 11, 178-186. doi: 10.1176/appi. focus.11.2.178

Berne, E. (2016). Transactional analysis in psychotherapy: A systematic individual and social psychiatry. New York: Hauraki Publishing.

Blatner, A. (2000). Foundation of psychodrama. (4th ed). New York: Springer Publishing Company, Inc.

Boden, J. M., Fergusson, D. M.,\& Horwood, L. J. (2007). Self-esteem and violence: Testing links between adolescent self-esteem and later hostility and violent behavior. Social Psychiatry and Psychiatric Epidemiology, 42, 881-891. doi: 10.1007/s00127-0070251-7

Burden, R. (2005). Dyslexia and self-concept seeking a Dyslexic identity. London, England: Whurr Publishers.

Burden, R. (2008). Is dyslexia necessarily associated with negative feelings of self-worth? A review and implications for future research. Dyslexia, 14, 188-196. 
Burden, R., \& Burdett, J. (2005). Factors associated with successful learning in pupils with dyslexia: A motivational analysis. British Journal of Special Education, 32, 100-104.

Burden, R., \& Burdett, J. (2007). What's in a name? Students with dyslexia: Their use of metaphor in making sense of their disability. British Journal of Special Education, 34, $75-79$.

Bushman, B. J., \& Anderson, C. A. (2001). Is it time to pull the plug on the hostile versus instrumental aggression dichotomy?. Psychological Review, 108(1), 273-279. doi: 10.1037/0033-295X.108.1.273

Corey, G. (2009). Teori dan praktek konseling dan psikoterapi. Bandung: Rafika Aditama.

Dayton, T. (1990). Drama games: Techniques for self-development. Deerfield Beach, FL: Health Communications.

Eadon, H. \& British Dyslexia Association (2005). Dyslexia and drama. Abingdon, UK: Routledge David Fulton Publishers.

Erikson, E. H. (1940). Studies in the interpretation of play. Genetic Psychology Monographs, 22(4), 557-671.

Fifin. (2009). Efektivitas Penggunaan Teknik Psikodrama untuk Meningkatkan Kepercayaan

Diri Siswa Kelas VII SMP Negeri 1 Krembung Sidoarjo. at http://karyailmiah.um.ac.id/index.php/BK-Psikologi/article/view/5778 diunduh 10 desember 2018

Firman. (2009). Efektivitas Terapi Permainan Psikodrama Untuk Mengembangkan Ketrampilan Emosional Pada Anak Retardasi Mental Ringan. at http://www.kesimpulan.com/2009/03/efektivitas-terapi-permainan-psikodrama.html diunduh 10 desember 2018

Foss, Ben. (2013). The Dyslexia Empowerment Plan. New York: Ballantine Books.

Glazzard, J. (2010). The impact of dyslexia on pupil's self-esteem. Support for Learning, 25, 63-69.

Humphrey, N. (2002). Teacher and pupil ratings of self-esteem in developmental dyslexia. British Journal of Special Education, 29, 29-36

Maklum. (2011). Psikodrama . at http://id.shvoong.com/social-sciences/counseling/2182171psikodrama/ diunduh 10 desember 2018

Mash, E. J., \& Wolfe, D. A. (2016). Abnormal Child Psychology (sixth edit). USA: Cengage Learning. https://doi.org/10.4324/9780203893258 
Mohamad, N., Esmaiel, B., Spuran, R. (2006). The impact of psychodrama on social skills and self-esteem of elementary school students with dyslexia. Journal of Exceptional Children, 6(2).

Morrison, GR, Ross, SM, \& Kemp, JE (2012). Merancang instruksi yang efektif(7th ed.). New York: John Wiley.

Muthoharoh, Hafiz. (2010). Metode Psikodrama dan Bermain Peranan (Role Playing Method) .at http://alhafizh84.wordpress.com/2010/01/16/metode-psikodrama-dan-bermainperan n-role-playing-method/ diunduh 10 desember 2019

Reid, G. (2011). Dyslexia: A Complete Guide for Parents and Those Who Help Them: Second Edition. https://doi.org/10.1002/9781119970897

Riddick, B. (2010). Living with Dyslexia: The Social and Emotional Consequences of Specific Learning Disabilities/Difficulties. Routledge. London

Riddick, B., Sterling, C., Farmer, M., \& Morgan, S. (1999). Self-esteem and anxiety in the educational histories of adult dyslexic students. Dyslexia, 5, 227-248.

Riley, K., \& Rustique-Forrester, E. (2002). Working with disaffected Students: Why students lose interest in school and what we can do about it. London, England: Paul Chapman.

Santrock, John W. (2009). Life-span Development, (12th ed.). New York: McGraw-Hill.

Singer, E. (2005). The strategies adopted by Dutch children with dyslexia to maintain their self-esteem when teased at school. Journal of Learning Disabilities, 38( 5), 23-411.

Smilansky, S., \& Shefatya, L. (1990). Facilitating play. Gaithersburg, MD: Psychosocial and Educational Publications.

Turner, H., Mayall, B., Dickinson, R., Clark, A., Hood, S., Samuels, J., \& Wiggins, M. (2004). Children engaging with drama: An evaluation of the National Theatre's drama work in primary schools 2002-2004. London, England: Social Science Research Unit, Institute of Education, University of London.

Velotti, P., \& Garofalo, C. (2015). Personality styles in a non-clinical sample: The role of emotion dysregulation and impulsivity. Personality and Individual Differences, 79, 4449. doi: 10.1016/j.paid.2015.01.046

Wati, P. (2019) Psikodrama untuk Meningkatkan Relasi Pertemanan Siswa SMP Negeri 1 Sawit Boyolali. Thesis thesis, Universitas Muhammadiyah Surakarta

Westwood, P. (2004). Learning and learning difficulties. (T. Rainer \& V. Rainer, Eds.). Cameberwel, Victoria: ACER Press. 
Wilkins, P. (1999). Psychodrama. Sage Publications. London-California-New Delhi.

Wingkel . (2004). Bimbingan dan Konseling di Institusi Pendidikan. Jakarta : PT. Gramedia 